\title{
Evidence of subducted Archean nitrogen in the Siberian Craton
}

\section{P. H. Barry ${ }^{1 *}$, M.W. Broadley ${ }^{2}$}

${ }^{1}$ WHOI, Woods Hole, MA, 02543, USA (pbarry@whoi.edu)

${ }^{2}$ CRPG, Université de Lorraine, Nancy, France

(broadley@crpg.cnrs-nancy.fr)

Crustally-derived xenoliths (Gt, Cpx and $\mathrm{Ol}$ ) from Siberia are originally derived from subducted oceanic crust which has since amalgamated to form the Siberian craton. For example, the occurrence of non-mantle-like oxygen isotope signatures in Siberian xenoliths suggests that these lithologies are artifacts of partially-melted subducted ocean crust $[1,2]$. The ages of Siberian xenoliths are constrained to be within 2.7 3.1 Ga using Re-Os and Sm-Nd isotope dating techniques [3].

In order to assess if nitrogen is also recycled in ancient subducted-oceanic crust we determined $\mathrm{N}$-isotopes $\left(\delta^{15} \mathrm{~N}\right)$ and $\mathrm{N}_{2} / \mathrm{Ar}$ values for a suite of peridotitic and eclogitic xenoliths $(n=10)$ from two petrologically-distinct kimberlite pipes (i.e., Udachnaya and Obnazhennaya). Due to the antiquity of these particular xenoliths, they represent prime targets to understand the temporal evolution of N-isotopes in Earth's mantle, which has previously been suggested to show a secular variation throughout Earth history [4].

$\mathrm{N}$-isotopes $\left(\delta^{15} \mathrm{~N}\right)$ of Siberian xenoliths range from -5.9 to $3.9 \%$ (vs. air) consistent with both upper (MORB $=-5 \pm 2$ $\%$ ) and lower (plume $=+6 \pm 2 \%$ ) mantle contributions. Notably, all Obnazhennaya samples display $\mathrm{N}$-isotope values in the MORB range or slightly above, whilst Udachnaya samples span the entire range of values reported here. $\delta^{15} \mathrm{~N}$ in Udachnaya xenoliths is inversely correlated with $\mathrm{Br} / \mathrm{Cl}$ [4], with the lowest $\delta^{15} \mathrm{~N}$ values exhibiting the highest $\mathrm{Br} / \mathrm{Cl}$. The high $\mathrm{Br} / \mathrm{Cl}$ within Udachnaya has previously been interpreted as evidence for an altered oceanic crust contribution [4]. Here, we suggest that the low $\delta^{15} \mathrm{~N}$ values in Udachnaya are also the result of Archean subduction of oceanic crust containing kerogens with isotopically low $\delta^{15} \mathrm{~N}$ signatures [5]. The range of $\delta^{15} \mathrm{~N}$ measured within Udachnaya can therefore be explained by mixing between an Archean subducted oceanic crustal component and plume component, whereas Obnazhennaya samples require an admixture of MORB and plume sourced $\mathrm{N}$, which is consistent with He isotope values measured in the same samples [6], which show upper mantle overprinting of a pervasive plume component.

[1] MacGregor and Manton, 1986. [2] Taylor and Anand, 2004. [3] Pearson et al., 1995. [4] Broadley et al., 2018.

[5] Beamont and Robert, 1999. [6] Barry et al., 2015. 